sciendo

10.2478/aucft-2021-0014

\title{
CHEMICAL CHARACTERISTICS OF LIMOUSINE BEEF DEPENDING ON FINISHING DIETS AND MUSCLE TYPE OF MEAT
}

\author{
- Research paper -
}

\begin{abstract}
Konrad WIŚNIEWSKI ${ }^{* 1}$, Barbara WRÓBEL ${ }^{* *}$, Jerzy BARSZCZEWSKI ${ }^{* *}$, Tomasz SAKOWSKI*** $^{* *}$ Beata KUCZYŃSKA*

*Department of Animal Breeding, Institute of Animal Science, Warsaw University of Life Sciences, 8 Ciszewskiego Str., 02-786 Warsaw, Poland

**Department of Grassland Farming, Institute of Technology and Life Sciences, Falenty, 3 Aleja Hrabska Str., 05-090 Raszyn, Poland

***Department of Biotechnology and Nutrigenomics, Institute of Genetics and Animal Biotechnology of the Polish Academy of Sciences, Jastrzębiec, 36A Postępu Str, 05-552 Magdalenka, Poland
\end{abstract}

\begin{abstract}
The goal of this study was to compare the chemical properties of three muscle types of beef cattle fed using different finishing diets compositions. Four finishing feeding models for bulls based on different proportions of concentrates, maise silage, grass silage and hay were evaluated. Muscles chemical composition was evaluated in $m$. infraspinatus (ISB), m. longissimus thoracis (LTC) and $m$. longissimus lumborum (LLS). The chemical composition of meat was influenced by muscle type. ISB was characterised by higher moisture, collagen content, lower protein and ash content, and net energy concentration than LTC and LLS. The differences between diets in dry matter and fat content in each of the muscle groups studied were stated. Furthermore, a difference in the collagen content in LLS and protein content in ISB was noted. High correlations $(\mathrm{P} \leq 0.05)$ were found between the concentrate content in the finishing diet and protein content $(r=0.59)$ in ISB, and dry matter both in LLS $(r=0.69)$ and LTC $(r=0.58)$. The lowest fat content of beef was noted for all muscles obtained from animals fed with a diet composed of grass silage, hay, and concentrates (D1).
\end{abstract}

Keywords: moisture, protein, collagen, fat, ash, Limousine,

\section{INTRODUCTION}

Beef production is an essential branch of E.U. agriculture. In Poland it is also playing an increasingly important role (Seremak Bulge, 2014), not only in conventional but in an organic system too (Biel et al., 2019). However, the main factor limiting beef production, also in Poland, is its low profitability. Polish farmers are looking for solutions aimed at lowering the cost of production. Calculations of profitability for beef production and the analysis of the percentage structure of unit costs indicate the importance of feeding as the most significant factor influencing profitability. There is a need for improving efficiency by decreasing feeding costs and increasing daily body weight gains.

Received: 16.04.2021

Accepted in revised form: 10.06.2021
While there are many feeding systems for beef cattle in Poland, the most popular is the semi-intensive feeding system in which 6-month-old cattle are placed on pasture for grazing. Grazing for 180 days is followed by intensive feeding using conserved forages supplemented with concentrates to attain daily live weight gains of approximately $1500 \mathrm{~g}$ (Nogalski et al., 2014). In central and northern Europe, the cheapest source of nutrients for beef cattle feeding is foraging from permanent grasslands, including pasture in the summer and winter - grass silage or bale grazing. Grass silage is usually supplemented with grain in intensive production to increase nutrient and energy intake (Purwin et al., 2016) (Randby et al., 2010) (Steen et al., 2002). Maise silage has been used as a good roughage for cattle fattening (Nogalski et al., 2014) (Keady et al., 2013) (Fraser et al., 2009). In turn, this

${ }^{1}$ Corresponding authors. E-Mail address: Konrad_Wisniewski@sggw.edu.pl 
requires even protein and energy supplementation to meet the nutritional needs of the animal. It is worth noting that maise silage is more beneficial to the animal than grass silage. It depends on many factors: botanical composition of sward, development phase at harvest, and harvest and conservation technology (Kenneth et al., 2020).

Since the significant cost factor for winter finishing is the price of concentrates, the amounts of dietary concentrate input are limited while ensuring the production of carcasses with required specifications for the European market. A high level of fattening efficiency can provide good quality grass silage with or without supplementation with concentrate (Steen et al., 2020) (Pesonen et al., 2014) (Randby et al., 2010). The use of low-quality forages increases the time for finishing and increases quantities of feed and resultant feed costs due to greater use of concentrates while decreasing meat quality (Purwin et al., 2016).

The Limousin breed is commonly used in Poland for beef production. Popular beef cuts are striploin $(m$. longissimus lumborum) and cube (m. longissimus thoracis) (Aldai et al., 2012). Cattle nutrition affects the quality of the beef (French et al., 2001) (Webb, 2006) through, inter alia, the type of feeding, i.e. the nutritional composition of the feed (Purwin et al.,

\section{MATERIALS AND METHODS}

\section{Feeding experiments}

Research has been conducted in farms in northeastern Poland specialising in the breeding of Limousin cattle. For the experiment, 40 Limousin intact bulls spring-born and fall-weaned (ten bulls from every farm) were selected from the beef herds. The initial weights of bulls in particular farms hesitated from $270 \pm 26$ to $352 \pm 44 \mathrm{~kg}$. On each farm, the calves were kept with their dams until weaning, managed on pastures containing 20\% white clover. Calves were removed from their dams at the end of the pasture season (in October) and placed in barns. The separated bulls intended for fattening were kept in a free-standing system.

They were fed with different finishing diets (D1, D2, D3 and D4). To provide resources in every
2006) (Steen et al., 2002). Subsequently, carcass quality following the EUROP scheme influences the price the producer receives (Choi et al., 2000). Forage quality, including protein and energy content, determines both body weight gains and meat quality from permanent grasslands, affecting production costs and financial returns.

The current knowledge beef production counts with many challenges ( e.g. increasing weight gain, reducing greenhouse gas level, reducing oxidation in tissues), which realised using novel feed strategies, e.g. grass pasture with natural vegetal bioactive substances - phytochemicals (Pena-Torres et al., 2019). Reducing production costs on many farms is limited due to failure to optimise feeding strategy using available feed resources. The effect of the concentrate level has been extensively investigated on the cattle productivity during the fattening period (Steen et al., 2002) (Keane et al., 2006). Experience shows the impact of using good quality forage from grasslands to reduce the number of concentrates in finishing diets on the quality of beef. The aim of the study was to compare three samples of beef cattle in terms of chemical properties fed with different compositions of finishing diets.

farm, diets for finishing purposes contained: grass silage, hay, silage from maise and concentrated fodder (grain meal). Table 1 presented the composition of finishing diets in particular farms and mean daily feed intake.

All ingredients were supplied to the animals separately. Diet composition resulted from the actual nutritional value of feeds, considered animal demands, and assumed daily live weight gain in particular feeding periods. Finishing diets were formulated based on nutrient requirements established by INRA (2001) using INRATion software (Kowalski and Kański, 1993). Animals had permanent access to water and saltlicks. After obtaining by cattle bodyweight exceeding $500 \mathrm{~kg}$ fattening period was finish and cattle went to slaughter.

Table 1. Composition of finishing diets (\%) and mean daily feed intake (kg/DM)

\begin{tabular}{|c|c|c|c|c|}
\hline \multirow{2}{*}{} & \multicolumn{5}{|c|}{ Finishing diet } \\
\cline { 2 - 5 } & D1 & D2 & D3 & D4 \\
\hline Grass silage & 60 & 75 & - & 60 \\
\hline Maise silage & - & 22 & 54 & 40 \\
\hline Meadow hay & 30 & - & 42 & - \\
\hline Concentrate & 10 & 4 & 4 & - \\
\hline Mean intake (kg of DM) & 9.54 & 10.43 & 8.10 & 8.02 \\
\hline
\end{tabular}

DM - dry matter 


\section{Nutritive value of forage}

Once a month during the experiment, feed samples were collected for nutrient analysis. The NIRS method (PN-EN ISO 12099:2017-10, 2019) using NIRFlex N-500 apparatus with ready-for-use calibrations provided by INGOT ${ }^{\circledR}$ was used to assess the nutrient composition of hay, grass silage, maise silage and concentrates. According to the INRA system (2001), the nutritive value of fodder was determined based on chemical composition and calculated with INWAR for Windows 1.6 software (Kowalski and Kański, 1993). Table 2 presented the chemical composition of finishing diets.

\section{Meat samples preparation}

The animals from each farm, similar to body weight, were assigned for meat quality analysis. All the animals were slaughtered at the age of 18 months. Beef from the examined bulls was characterised by a hot carcass weight of $353 \pm 27 \mathrm{~kg}$ ( 326 to $380 \mathrm{~kg}$ ). Bulls were transported to the nearest slaughter point, located only within a radius of $50 \pm 30 \mathrm{~km}$ from the farms. The slaughter procedure in the slaughterhouse consisted of stunning the animal by electrical stimulation. According to ICAR (2018) requirements, the temperature of cooling the carcasses was valid throughout the European Union. Carcasses were aged at $4^{\circ} \mathrm{C}$ for 5 days post-mortem. Three pieces of meat were obtained from each animal, including $m$. infraspinatus from the blade (ISB), m. longissimus thoracis from the cube (LTC) and the m. longissimus lumborum (LLS) from the striploin. Striploin was boneless and came from the short loin consisting of the Longissimus lumborum, this part dedicated to steak. Beef cattle meat was obtained from a commercial abattoir. After slaughter, the meat was aged for two to five days as carcasses in $4^{\circ} \mathrm{C}$ temperature and afterwards as steaks in a vacuum at a $0^{\circ} \mathrm{C}$ temperature.

\section{The basic chemical composition}

Based on the content of crude protein, moisture, intramuscular fat and collagen by the near infrared transmission spectrometric method (NIRS) by the method (PN-A-82109: 2010), the basic chemical composition of raw meat was determined. The beef samples were homogenised and then were placed in a measuring cell of a FoodScan analyser. The device uses the near-infrared transmission method within the $850-1050 \mathrm{~nm}$ range and artificial neural networks. The analysis was carried out by indicating the number of 16 measurements in the sample in the computer software, then the program automatically calculated the average and presented the results.

\section{Statistical analyses}

Meat attributes were assessed by analysis of variance using two-way ANOVA (Statistica v.6). Calculated were for each variable means and standard deviation (S.D.). The type of finishing diet and muscle type was considered a fixed factor, with three replicates per treatment for each analysis of meat. When differences were statistically significant, a Tukey's test was performed with statistical significance set at $\mathrm{p}=0.05$. The correlations between meat attributes and diet components were evaluated using the Pearson correlation coefficient.

Table 2. Average nutrient concentration in feeding diets

\begin{tabular}{|l|c|c|c|c|}
\hline \multirow{2}{*}{} & \multicolumn{4}{|c|}{ Finishing diet } \\
\cline { 2 - 5 } & D1 & D2 & D3 & D4 \\
\hline Dry matter $\left(\mathrm{g} \mathrm{kg}^{-1} \mathrm{DM}\right)$ & 670.0 & 639.8 & 607.6 & 386.9 \\
\hline Total protein $\left(\mathrm{g} \mathrm{kg}^{-1} \mathrm{DM}\right)$ & 147.2 & 122.0 & 114.7 & 118.6 \\
\hline Crude ash $\left(\mathrm{g} \mathrm{kg}^{-1} \mathrm{DM}\right)$ & 90.9 & 62.1 & 54.9 & 67.1 \\
\hline Crude fat $\left(\mathrm{g} \mathrm{kg}^{-1} \mathrm{DM}\right)$ & 44.9 & 30.8 & 38.6 & 38.0 \\
\hline Crude fibre $\left(\mathrm{g} \mathrm{kg}^{-1} \mathrm{DM}\right)$ & 389.0 & 259.3 & 206.8 & 243.5 \\
\hline NDF $\left(\mathrm{g} \mathrm{kg}^{-1} \mathrm{DM}\right)$ & 718.3 & 530.5 & 427.7 & 459.6 \\
\hline UFV & 0.73 & 0.71 & 0.78 & 0.71 \\
\hline
\end{tabular}

DM - dry matter; NDF - Neutral detergent fibre; UFV - Feed Unit for meat production

\section{RESULTS AND DISCUSSION}

The basic chemical composition of the different beef cuts is presented in Table 3. Statistical analysis showed a few differences in the tested material. Our study significant differences between finishing diets only in moisture content and fat content in each of the studied muscle groups were stated.
Furthermore, a difference in the collagen content in the longissimus lumborum of striploin (LLS) and protein content in the infraspinatus muscle (ISB) was noted. No differences were stated in ash content.

The moisture content in examined beef cuts was influenced by feeding treatment. The lowest moisture content matter $(73.77 \%)$ was noted for all 
beef cuts obtained from animals fed with a diet composed of grass silage, hay, and concentrates (D1). Moisture content in meat from animals fed with remaining diets (D2, D3 and D4) was significantly higher $(>74,0 \%)$. Significant differences in moisture content between cuts were also observed. The highest moisture content, independently from feeding treatment, was found in the infraspinatus muscle (ISB). In LLS and LTC, moisture content was significantly lower and was below $75,0 \%$

The total fat content of beef reflects feeding regime and genetic variability between cattle breeds, age at harvest, carcass grade, and beef cut. Fat concentrations in examined samples were remarkably diverse. It hesitated from $1.23 \pm 0.058 \%$ in LLS from animals fed with diet D1 to $2.49 \pm 0.26 \%$ in ISB from animals fed with diet basing on grass- and maise silage (D4). It was influenced by providing treatment and type of cut. The lowest fat contents were noted for all beef cuts obtained from animals fed with a diet composed of grass silage, hay, and concentrates (D1). It hesitated from $1.23 \pm 0.08 \%$ in the longissimus lumborum of striploin (LLS) to $1.77 \pm 0.13 \%$ in Infraspinatus of the blade (ISB). Significantly higher fat contents were found in cuts in animals fed with diet D2 (grass silage, maise silage and concentrate) and diet D3 (maise silage, hay, and concentrates). The highest fat content $(2.27 \pm 0,26 \%)$ was found in cuts from animals fed with diet D4 without concentrate. Several study presented the lowest fat content in range $0,56-0,88 \%$ were found in the muscles of the local breeds. The meat of our experimental Limousine bulls have been had higher fat content $(1,37-2,49)$ than that of the Polish Holstein Friesian bulls $(1,28-1,49 \%)$, and higher than the Simmentals (0,70-1,27\%) (Litwińczuk et al. (2016)

The protein content hesitated from $21.60 \pm 0.36 \%$ in ISB from animals fed with diet D4 to $24.84 \pm 0.27 \%$ in LLS from animals fed with D1. Protein content depended on the beef cut. Mean protein content, independently of the finishing diet composition, in LLS and LTC exceeded $24 \%$ and was significantly higher than in the Infraspinatus of the blade (ISB) $(21.95 \pm 0.51 \%)$. Effect of feeding treatment on protein content was found only for ISB. The lowest protein content $(21.60 \pm 0.36 \%)$ was found in this muscle from animals fed with diet D4, higher in muscle from animals fed with diets D2 and D3 and the highest $(22.63 \pm 0.42 \%)$ in muscle from animals fed with D1.

Moisture to protein ratio, first of all, depended on the beef cut. Independently on the finishing diet composition, it was higher in ISB than in LLS and LTC. Effect of feeding treatment on moisture to protein ratio was found only for ISB. The lowest moisture to protein content $(3.26 \pm 0.05)$ was found in this muscle from animals fed with diet D1 and significantly higher in muscle from animals fed with other diets.

Ash content hesitated from $1.13 \pm 0.03 \%$ in ISB from animals fed with diet D4 to $1.30 \pm 0.03 \%$ in LTC in animals from D4 and $1.30 \pm 0.01 \%$ in LLS animals from D1 and was independent on feeding treatment. Significant differences in ash content between cuts were stated. The lowest ash content, independently from feeding treatment, was found in ISB $(1.15 \pm 0.03 \%)$. In LLS and LTC, ash content was significantly higher and in both cases was similar - $1.26 \pm 0.06 \%$

Collagen plays a vital role in cooked beef. When the collagen fibres are heated during cooking, they shrink, causing fluid loss and less tender beef. Collagen makes up a few per cent of the weight of strong, sinewy muscles and one to two per cent of muscle mass. Collagen content, like protein, ash and dry matter content, also depended on the beef cut. Mean collagen content was visibly higher in ISB (where its content exceeded 1.76\%) than in LLS and LTC. The significant influence of finishing diet composition on collagen content was proved only in LLS. The lowest collagen content in this muscle $(0.80 \pm 0.02 \%)$ was measured in animals fed with a diet composed of grass silage, hay and concentrates (D1). The highest collagen content was significantly stated in muscles from animals fed with diet D2 $(1.01 \pm 0.08 \%)$ and D4 $(0.96 \pm 0.04 \%)$. In the studies of other authors, the content of this component in the LTC was lower. In this muscle of young bulls and dairy cows of local breeds, insoluble and total collagen content was on average $0.32 \%$ and $0.24 \%$. Of the 15 cattle, breeds tested the lowest was showed in the Piemontese and Limousin meat breeds, $0.28 \%$ and $0.21 \%$, respectively (Christensen et al., 2011). Blanco et al. (2013) conducted the meta-analysis that the meat of cattle of local dairy breeds has a higher total collagen content than meat breeds' meat. This tendency was confirmed in the Litwińczuk et al. (2016) study.

The study was showed the content of collagen depended only on the beef cut, and in the ISB, the muscle was nearly two times higher than in the other cuts. 
Table 3. Chemical composition (\%) of beef fed with different finishing diets

\begin{tabular}{|c|c|c|c|c|c|c|}
\hline \multirow{2}{*}{$\begin{array}{c}\text { Examined } \\
\text { parameters }\end{array}$} & \multirow{2}{*}{ Muscle } & \multicolumn{5}{|c|}{ Finishing diet } \\
\hline & & D1 & D2 & D3 & D4 & Mean for diets \\
\hline \multirow[t]{4}{*}{ Moisture (\%) } & ISB & $\begin{array}{l}73.78 \\
\pm 0.04^{\mathrm{c}}\end{array}$ & $\begin{array}{c}75.90 \\
\pm 0.12^{\mathrm{ab}}\end{array}$ & $\begin{array}{c}76.45 \\
\pm 0.45^{\mathrm{a}}\end{array}$ & $\begin{array}{l}75.49 \\
\pm 0.14^{\mathrm{b}}\end{array}$ & $\begin{array}{c}75.41 \\
\pm 1.03 \mathrm{~B}\end{array}$ \\
\hline & LLS & $\begin{array}{r}73.86 \\
\pm 0.18 \mathrm{a} \\
\end{array}$ & $\begin{array}{r}74.86 \\
\pm 0.18 \mathrm{~b} \\
\end{array}$ & $\begin{array}{r}74.39 \\
\pm 0.15^{\mathrm{ab}} \\
\end{array}$ & $\begin{array}{r}74.48 \\
\pm 0.19 \mathrm{~b} \\
\end{array}$ & $\begin{array}{r}74.40 \\
\pm 0.40 \mathrm{~A} \\
\end{array}$ \\
\hline & LTC & $\begin{array}{r}73.66 \\
\pm 0.18 \mathrm{a} \\
\end{array}$ & $\begin{array}{r}74.73 \\
\pm 0.13 \mathrm{~b} \\
\end{array}$ & $\begin{array}{r}74.34 \\
\pm 0.11 \mathrm{~b} \\
\end{array}$ & $\begin{array}{r}74.32 \\
\pm 0.23 \mathrm{~b} \\
\end{array}$ & $\begin{array}{c}74.27 \\
\pm 0.42 \mathrm{~A}\end{array}$ \\
\hline & Mean & $\begin{array}{r}73.77 \\
\pm 0.17 a \\
\end{array}$ & $\begin{array}{r}75.16 \\
\pm 0.55 b \\
\end{array}$ & $\begin{array}{r}75.06 \\
\pm 1.02 \mathrm{~b} \\
\end{array}$ & $\begin{array}{r}74.76 \\
\pm 0.55 b \\
\end{array}$ & \\
\hline \multirow[t]{4}{*}{ Fat $(\%)$} & $I S B$ & $\begin{array}{c}1.77 \\
\pm 0.13^{\mathrm{a}} \\
\end{array}$ & $\begin{array}{c}2.02 \\
\pm 0.08^{\mathrm{ab}} \\
\end{array}$ & $\begin{array}{c}1.87 \\
\pm 0.25^{\mathrm{a}}\end{array}$ & $\begin{array}{c}2.49 \\
\pm 0.26^{\mathrm{b}}\end{array}$ & $\begin{array}{c}2.04 \\
\pm 0.32 \mathrm{~A} \\
\end{array}$ \\
\hline & $L L S$ & $\begin{array}{c}1.23 \\
\pm 0.08^{\mathrm{a}} \\
\end{array}$ & $\begin{array}{c}1.89 \\
\pm 0.15^{\mathrm{b}}\end{array}$ & $\begin{array}{c}2.01 \\
\pm 0.08^{\mathrm{b}}\end{array}$ & $\begin{array}{c}2.05 \\
\pm 0.23^{\mathrm{b}}\end{array}$ & $\begin{array}{c}1.80 \\
\pm 0.35 \mathrm{~A} \\
\end{array}$ \\
\hline & LTC & $\begin{array}{c}1.37 \\
\pm 0.11^{\mathrm{a}} \\
\end{array}$ & $\begin{array}{c}2.00 \\
\pm 0.14^{\mathrm{b}} \\
\end{array}$ & $\begin{array}{c}2.05 \\
\pm 0.11^{\mathrm{b}} \\
\end{array}$ & $\begin{array}{c}2.28 \\
\pm 0.17^{\mathrm{b}} \\
\end{array}$ & $\begin{array}{c}1.93 \\
\pm 0.36 A \\
\end{array}$ \\
\hline & Mean & $\begin{array}{c}1.46 \\
\pm 0.24^{a} \\
\end{array}$ & $\begin{array}{c}1.97 \\
\pm 0.12^{b} \\
\end{array}$ & $\begin{array}{c}1.98 \\
\pm 0.16^{b} \\
\end{array}$ & $\begin{array}{c}2.27 \\
\pm 0.26^{c} \\
\end{array}$ & \\
\hline \multirow[t]{4}{*}{ Protein $(\%)$} & $I S B$ & $\begin{array}{l}22.63 \\
\pm 0.42^{\mathrm{b}} \\
\end{array}$ & $\begin{array}{c}21.87 \\
\pm 0.52^{\mathrm{ab}} \\
\end{array}$ & $\begin{array}{c}21.70 \\
\pm 0.17^{\mathrm{ab}} \\
\end{array}$ & $\begin{array}{l}21.60 \\
\pm 0.36^{\mathrm{a}} \\
\end{array}$ & $\begin{array}{c}21.95 \\
\pm 0.51^{\mathrm{A}} \\
\end{array}$ \\
\hline & $L L S$ & $\begin{array}{l}24.84 \\
\pm 0.27^{\mathrm{a}}\end{array}$ & $\begin{array}{c}24.38 \\
\pm 0.28^{\mathrm{a}}\end{array}$ & $\begin{array}{l}24.47 \\
\pm 0.17^{\mathrm{a}}\end{array}$ & $\begin{array}{l}24.40 \\
\pm 0.63^{\mathrm{a}} \\
\end{array}$ & $\begin{array}{c}24.53 \\
\pm 0.36^{B}\end{array}$ \\
\hline & $L T C$ & $\begin{array}{l}24.70 \\
\pm 0.24^{\mathrm{a}} \\
\end{array}$ & $\begin{array}{l}24.32 \\
\pm 0.28^{\mathrm{a}} \\
\end{array}$ & $\begin{array}{l}24.36 \\
\pm 0.23^{\mathrm{a}} \\
\end{array}$ & $\begin{array}{l}24.28 \\
\pm 0.59^{\mathrm{a}} \\
\end{array}$ & $\begin{array}{c}24.41 \\
\pm 0.34^{B} \\
\end{array}$ \\
\hline & Mean & $\begin{array}{c}24.06 \\
\pm 1.05^{a} \\
\end{array}$ & $\begin{array}{c}23.52 \\
\pm 1.21^{\mathrm{a}} \\
\end{array}$ & $\begin{array}{c}23.51 \\
\pm 1.29^{a} \\
\end{array}$ & $\begin{array}{l}23.43 \\
\pm 1.37^{\mathrm{a}} \\
\end{array}$ & \\
\hline \multirow[t]{4}{*}{$\operatorname{Ash}(\%)$} & $I S B$ & $\begin{array}{c}1.16 \\
\pm 0.02^{\mathrm{a}} \\
\end{array}$ & $\begin{array}{c}1.14 \\
\pm 0.06^{\mathrm{a}} \\
\end{array}$ & $\begin{aligned} & 1.15 \\
& \pm 0.03^{\mathrm{a}} \\
&\end{aligned}$ & $\begin{array}{c}1.13 \\
\pm 0.03^{\mathrm{a}} \\
\end{array}$ & $\begin{array}{c}1.15 \\
\pm 0.03^{A} \\
\end{array}$ \\
\hline & $L L S$ & $\begin{array}{c}1.30 \\
\pm 0.01^{\mathrm{a}} \\
\end{array}$ & $\begin{array}{c}1.23 \\
\pm 0.08^{\mathrm{a}} \\
\end{array}$ & $\begin{array}{c}1.23 \\
\pm 0.08^{\mathrm{a}} \\
\end{array}$ & $\begin{array}{c}1.28 \\
\pm 0.04^{\mathrm{a}} \\
\end{array}$ & $\begin{array}{c}1.26 \\
\pm 0.06^{B} \\
\end{array}$ \\
\hline & LTC & $\begin{array}{c}1.28 \\
\pm 0.06^{\mathrm{a}} \\
\end{array}$ & $\begin{array}{c}1.22 \\
\pm 0.07^{\mathrm{a}} \\
\end{array}$ & $\begin{array}{c}1.24 \\
\pm 0.06^{\mathrm{a}} \\
\end{array}$ & $\begin{array}{c}1.30 \\
\pm 0.03^{\mathrm{a}} \\
\end{array}$ & $\begin{array}{c}1.26 \\
\pm 0.06^{\mathrm{B}}\end{array}$ \\
\hline & Mean & $\begin{array}{c}1.25 \\
\pm 0.07^{\mathrm{a}} \\
\end{array}$ & $\begin{array}{c}1.20 \\
\pm 0.07^{a} \\
\end{array}$ & $\begin{array}{c}1.21 \\
\pm 0.06^{a} \\
\end{array}$ & $\begin{array}{c}1.24 \\
\pm 0.08^{a} \\
\end{array}$ & \\
\hline \multirow[t]{4}{*}{ Collagen $(\%)$} & $I S B$ & $\begin{array}{c}1.71 \\
\pm 0.12^{\mathrm{a}} \\
\end{array}$ & $\begin{array}{c}1.78 \\
\pm 0.14^{\mathrm{a}} \\
\end{array}$ & $\begin{array}{c}1.76 \\
\pm 0.15^{\mathrm{a}} \\
\end{array}$ & $\begin{array}{c}1.80 \\
\pm 0.09^{\mathrm{a}} \\
\end{array}$ & $\begin{array}{c}1.76 \\
\pm 0.11^{\mathrm{B}} \\
\end{array}$ \\
\hline & $L L S$ & $\begin{array}{c}0.80 \\
\pm 0.02^{\mathrm{a}} \\
\end{array}$ & $\begin{array}{c}1.01 \\
\pm 0.08^{\mathrm{b}} \\
\end{array}$ & $\begin{array}{c}0.89 \\
\pm 0.05^{\mathrm{ab}} \\
\end{array}$ & $\begin{array}{c}0.96 \\
\pm 0.04^{\mathrm{b}} \\
\end{array}$ & $\begin{array}{c}0.92 \\
\pm 0.09^{\mathrm{A}} \\
\end{array}$ \\
\hline & LTC & $\begin{array}{c}0.97 \\
\pm 0.04^{\mathrm{a}} \\
\end{array}$ & $\begin{array}{c}0.96 \\
\pm 0.04^{\mathrm{a}} \\
\end{array}$ & $\begin{array}{c}0.94 \\
\pm 0.05^{\mathrm{a}} \\
\end{array}$ & $\begin{array}{c}0.94 \\
\pm 0.04^{\mathrm{a}} \\
\end{array}$ & $\begin{array}{c}0.95 \\
\pm 0.04^{\mathrm{A}} \\
\end{array}$ \\
\hline & Mean & $\begin{array}{c}1.16 \\
\pm 0.40^{a}\end{array}$ & $\begin{array}{c}1.25 \\
\pm 0.38^{a} \\
\end{array}$ & $\begin{array}{c}1.20 \\
\pm 0.40^{\mathrm{a}}\end{array}$ & $\begin{array}{c}1.23 \\
\pm 0.40^{\mathrm{a}}\end{array}$ & \\
\hline
\end{tabular}

ISB - Infraspinatus of blade; LLS - Longissimus lumborum of striploin; LTC - Longissimus thoracis of cube ${ }_{a, b}$ values within a row with the same superscripts differ significantly at $\mathrm{P} \leq 0.05$.

${ }^{A, B}$ values within a column with the same superscripts differ significantly at $\mathrm{P} \leq 0.05$.

The net energy of the muscle hesitated from $434.2 \pm 9.58 \mathrm{~kJ} / 100 \mathrm{~g}$ in ISB from animals fed with diet D3 to $492.9 \pm 11.66 \mathrm{~kJ} / 100 \mathrm{~g}$ in LTC in animals from D4. Significant differences in energy content between cuts and feeding treatments were stated (Table 4). The highest net energy concentration was observed for D4 treatment and the lowest for D1 treatment. Independently on feeding treatment, it was significantly lower in ISB and higher in LLS and LTC.

Some correlations between chemical components of beef cuts were found. Positive correlations were found between moisture and fat content for LTC and LLS. It is known that the fat content negatively correlates with the moisture content of beef (Figure 1). However, the moisture wasn't replaced by fat in our samples. 
Table 4. Moisture to protein ratio, the share of collagen in total protein and net energy of muscle of beef fed with different finishing diets

\begin{tabular}{|c|c|c|c|c|c|c|}
\hline \multirow{2}{*}{$\begin{array}{c}\text { Examined } \\
\text { parameters }\end{array}$} & \multirow{2}{*}{ Muscle } & \multicolumn{5}{|c|}{ Finishing diet } \\
\hline & & D1 & D2 & D3 & D4 & Mean for diets \\
\hline \multirow[t]{4}{*}{$\begin{array}{l}\text { Moisture/Protein } \\
\text { ratio }\end{array}$} & $I S B$ & $\begin{array}{r}3.26 \\
\pm 0.05 a \\
\end{array}$ & $\begin{aligned} & 3.47 \\
& \pm 0.07 \mathrm{~b} \\
&\end{aligned}$ & $\begin{array}{r}3.52 \\
\pm 0.03 \mathrm{~b} \\
\end{array}$ & $\begin{aligned} & 3.50 \\
& \pm 0.05 \mathrm{~b} \\
&\end{aligned}$ & $\begin{array}{c}3.44 \\
\pm 0.12 B \\
\end{array}$ \\
\hline & $L L S$ & $\begin{array}{r}2.97 \\
\pm 0.03 \mathrm{a}\end{array}$ & $\begin{array}{c}3.07 \\
\pm 0.03 \mathrm{a}\end{array}$ & $\begin{array}{c}3.04 \\
\pm 0.02 \mathrm{a}\end{array}$ & $\begin{aligned} & 3.05 \\
\pm & 0.07 \mathrm{a}\end{aligned}$ & $\begin{aligned} & 3.03 \\
\pm & 0.06 \mathrm{~A}\end{aligned}$ \\
\hline & $L T C$ & $\begin{array}{r}2.98 \\
\pm 0.03 \mathrm{a}\end{array}$ & $\begin{array}{c}3.07 \\
\pm 0.03 \mathrm{a}\end{array}$ & $\begin{array}{c}3.05 \\
\pm 0.03 \mathrm{a}\end{array}$ & $\begin{array}{c}3.06 \\
\pm 0.07 \mathrm{a}\end{array}$ & $\begin{aligned} & 3.04 \\
& \pm 0.06 \mathrm{~A}\end{aligned}$ \\
\hline & Mean & $\begin{array}{r}3.07 \\
\pm 0.14 a \\
\end{array}$ & $\begin{array}{c}3.21 \\
+0.19 a \\
\end{array}$ & $\begin{array}{r}3.20 \\
\pm 0.23 a \\
\end{array}$ & $\begin{array}{c}3.20 \\
\pm 0.22 \mathrm{a} \\
\end{array}$ & \\
\hline \multirow{4}{*}{$\begin{array}{c}\text { Share of collagen } \\
\text { in total protein } \\
(\%)\end{array}$} & $I S B$ & $\begin{array}{r}7.55 \\
\pm 0.54 \mathrm{a} \\
\end{array}$ & $\begin{array}{r}8.15 \\
\pm 0.62 \mathrm{a} \\
\end{array}$ & $\begin{array}{r}8.10 \\
\pm 0.60 \mathrm{a} \\
\end{array}$ & $\begin{array}{c}8.32 \\
\pm 0.43 \mathrm{a} \\
\end{array}$ & $\begin{array}{c}8.03 \\
\pm 0.62 B \\
\end{array}$ \\
\hline & $L L S$ & $\begin{array}{r}3.23 \\
\pm 0.04 \mathrm{a} \\
\end{array}$ & $\begin{array}{c}4.16 \\
\pm 0.25 \mathrm{~b} \\
\end{array}$ & $\begin{aligned} & 3.65 \\
& \pm 0.19 \mathrm{ab} \\
&\end{aligned}$ & $\begin{aligned} & 3.95 \\
& \pm 0.08 \mathrm{~b} \\
&\end{aligned}$ & $\begin{aligned} & 3.75 \\
& \pm 0.38 \mathrm{~A} \\
&\end{aligned}$ \\
\hline & $L T C$ & $\begin{array}{r}3.93 \\
\pm 0.17 \mathrm{a}\end{array}$ & $\begin{array}{r}3.96 \\
\pm 0.10 \mathrm{a}\end{array}$ & $\begin{aligned} & 3.87 \\
\pm & 0.19 a\end{aligned}$ & $\begin{aligned} & 3.86 \\
\pm & 0.05 \mathrm{a}\end{aligned}$ & $\begin{aligned} & 3.91 \\
&+0.15 A\end{aligned}$ \\
\hline & Mean & $\begin{array}{r}4.90 \\
+1.92 \mathrm{a} \\
\end{array}$ & $\begin{array}{r}5.42 \\
\pm 1.97 a \\
\end{array}$ & $\begin{array}{r}5.21 \\
+2.08 \mathbf{a} \\
\end{array}$ & $\begin{aligned} & 5.38 \\
&+2.10 a \\
&\end{aligned}$ & \\
\hline \multirow{4}{*}{$\begin{array}{l}\text { Net energy of the } \\
\text { muscles } \\
(\mathrm{kJ} / 100 \mathrm{~g})\end{array}$} & $I S B$ & $\begin{array}{r}445.9 \\
\pm 5.65 \mathrm{a}\end{array}$ & $\begin{array}{r}462.7 \\
\pm 7.95 \mathrm{a}\end{array}$ & $\begin{array}{r}434.2 \\
\pm 9.58 \mathrm{a}\end{array}$ & $\begin{array}{r}455.9 \\
\pm 3.29 \mathrm{a}\end{array}$ & $\begin{aligned} & 444.7 \\
\pm & 10.47 \mathrm{~A}\end{aligned}$ \\
\hline & $L L S$ & $\begin{array}{r}462.8 \\
\pm 4.79 \mathrm{a} \\
\end{array}$ & $\begin{array}{r}481.4 \\
\pm 3.41 \mathrm{~b} \\
\end{array}$ & $\begin{array}{r}485.7 \\
\pm 2.67 \mathrm{~b} \\
\end{array}$ & $\begin{array}{c}486.1 \\
\pm 13.44 b \\
\end{array}$ & $\begin{array}{c}478.7 \\
\pm 12.04 \mathrm{~B} \\
\end{array}$ \\
\hline & $L T C$ & $\begin{array}{r}465.4 \\
\pm 4.43 \mathrm{a} \\
\end{array}$ & $\begin{array}{c}482.7 \\
\pm 0.63 \mathrm{ab} \\
\end{array}$ & $\begin{array}{c}485.7 \\
\pm 2.72 \mathrm{ab} \\
\end{array}$ & $\begin{array}{r}492.9 \\
\pm 11.66 \mathrm{~b} \\
\end{array}$ & $\begin{array}{c}481.7 \\
+11.96 \mathrm{~B} \\
\end{array}$ \\
\hline & Mean & $\begin{array}{r}458.0 \\
\pm \text { 9.99a }\end{array}$ & $\begin{array}{c}468.5 \\
\pm \text { 18.94ab }\end{array}$ & $\begin{aligned} & 465.5 \\
+ & 24.98 \mathrm{ab}\end{aligned}$ & $\begin{array}{c}478.3 \\
\pm 19.17 \mathrm{~b}\end{array}$ & \\
\hline
\end{tabular}

ISB - Infraspinatus of blade; LLS - Longissimus lumborum of striploin; LTC - Longissimus thoracis of cube a,b values within a row with the same superscripts differ significantly at $\mathrm{P} \leq 0.05$.

$\mathrm{A}, \mathrm{B}$ values within a column with the same superscripts differ significantly at $\mathrm{P} \leq 0.05$.

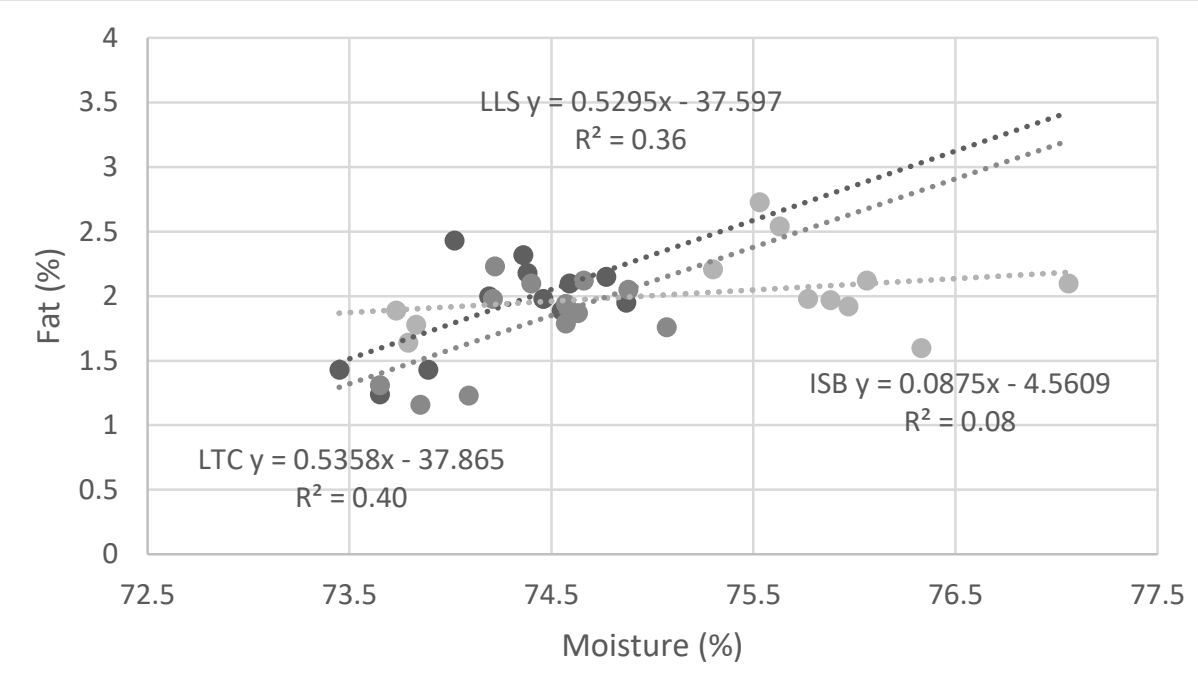

Figure 1. Relationship between moisture $(\%)$ and fat content $(\%)$ of various bovine muscles: ISB - Infraspinatus of a blade; LLS - Longissimus lumborum of striploin; LTC - Longissimus thoracis of a cube

Proteins have a high water-binding capacity in muscles. Significantly high negative correlations were observed between moisture and protein content for all cuts (Figure 2).
No significant correlations were found between moisture and ash content (Figure 3) and moisture and collagen in ISB and LTC (Figure 4). However, 
only between moisture and collagen for LLS a highly positive correlation was found.

A significantly high correlation $(\mathrm{P} \leq 0.05)$ between the share of feeds in the diet and basic meat compositions in all meat cuts are presented in Table 4. Between concentrate content in finishing diet and protein content $(r=0.59)$ in ISB was observed a positive correlation, and dry matter both in LLS ( $\mathrm{r}=$ $0.69)$ and LTC $(r=0.58)$. Between concentrate and fat content in all meat cuts and collagen only in LLS $(\mathrm{r}=-0.80) \quad$ (Table 5) was stated a negative correlation. Maize silage was positively correlated with fat content in LLS $(r=0.71)$ and in LTC $(r=$ $0.69)$ and negatively with moisture $(r=-0.73)$ and protein content $(\mathrm{r}=-0.62)$ in ISB. Correlations between hay in finishing diets were found only in cases of fat content in ISB $(r=-0.67)$. No significant correlations were found between grass silage and any other meat composition parameters. Between the content of fat and protein, collagen and ash in any muscle (Figures 5, 6, 7), no significant correlations were found.

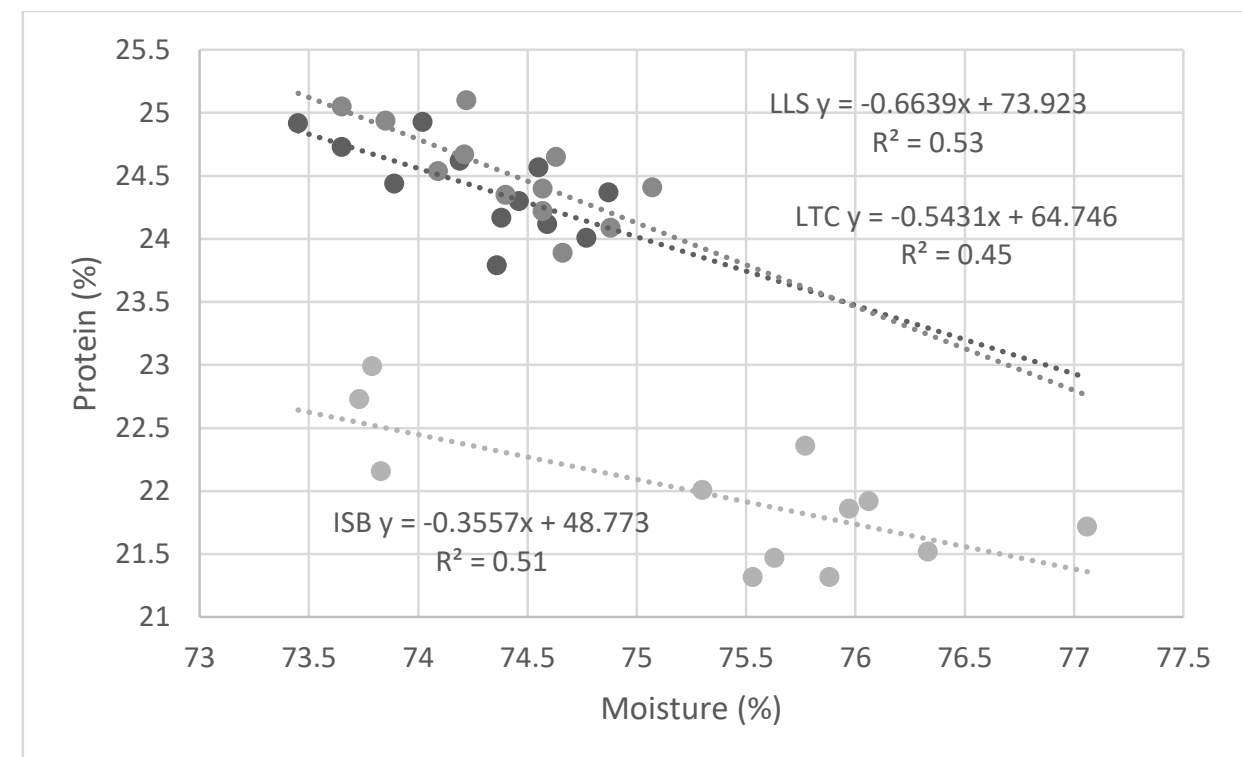

Figure 2. Relationship between moisture (\%) and protein content $(\%)$ of various bovine muscles: ISB Infraspinatus of a blade; LLS - Longissimus lumborum of striploin; LTC - Longissimus thoracis of a cube

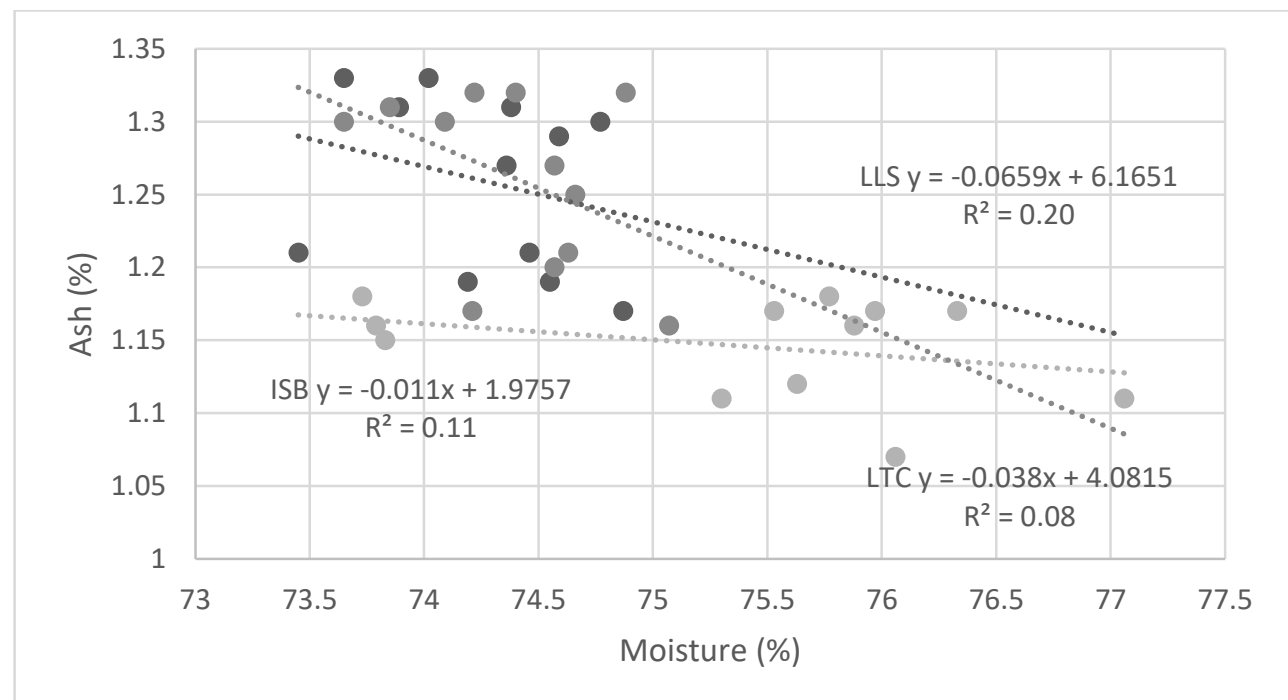

Figure 3. Relationship between moisture (\%) and ash content (\%) of various bovine muscles: ISB - Infraspinatus of a blade; LLS - Longissimus lumborum of striploin; LTC - Longissimus thoracis of a cube 


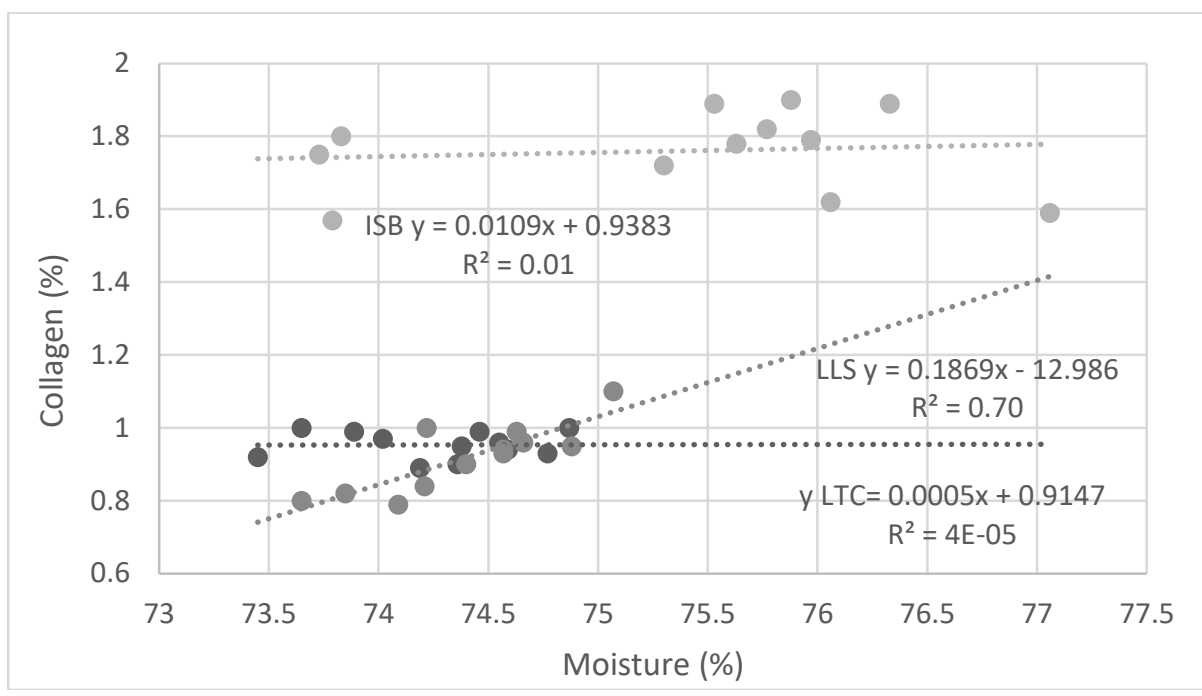

Figure 4. Relationship between moisture (\%) and collagen content $(\%)$ of various bovine muscles: ISB Infraspinatus of a blade; LLS - Longissimus lumborum of striploin; LTC - Longissimus thoracis of a cube

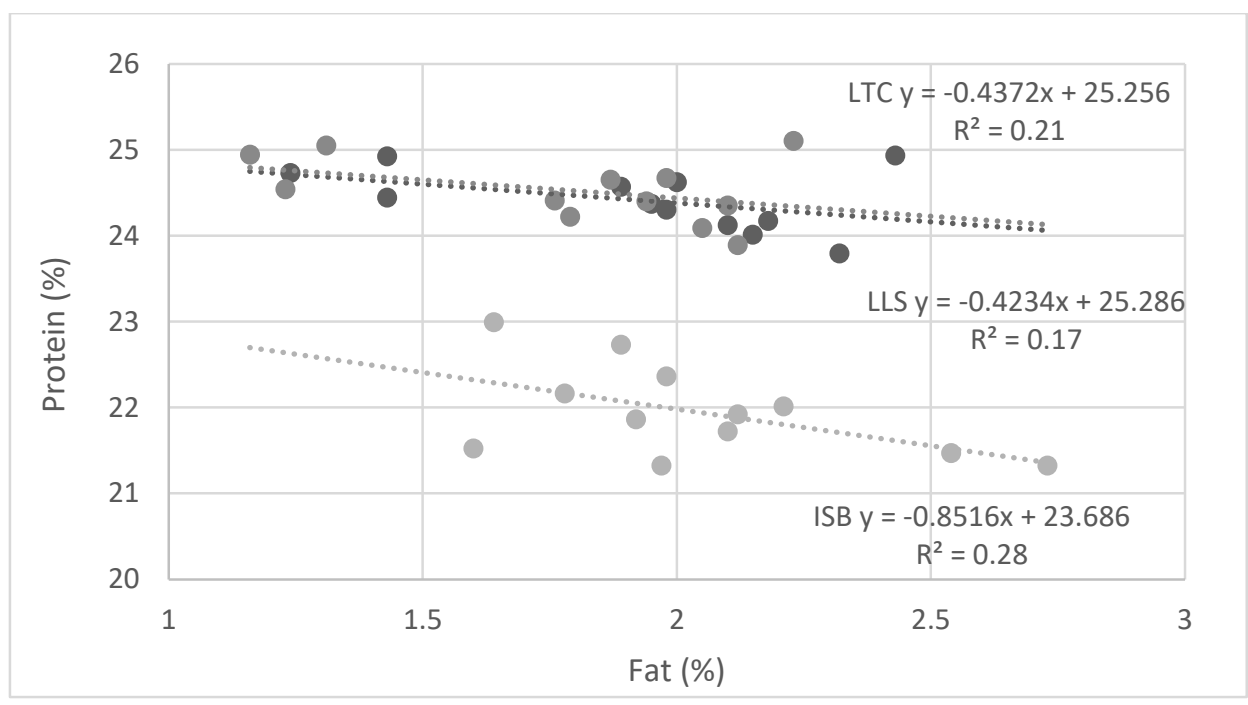

Figure 5. Relationship between fat (\%) and protein content (\%) of various bovine muscles: ISB - Infraspinatus of a blade; LLS - Longissimus lumborum of striploin; LTC - Longissimus thoracis of a cube

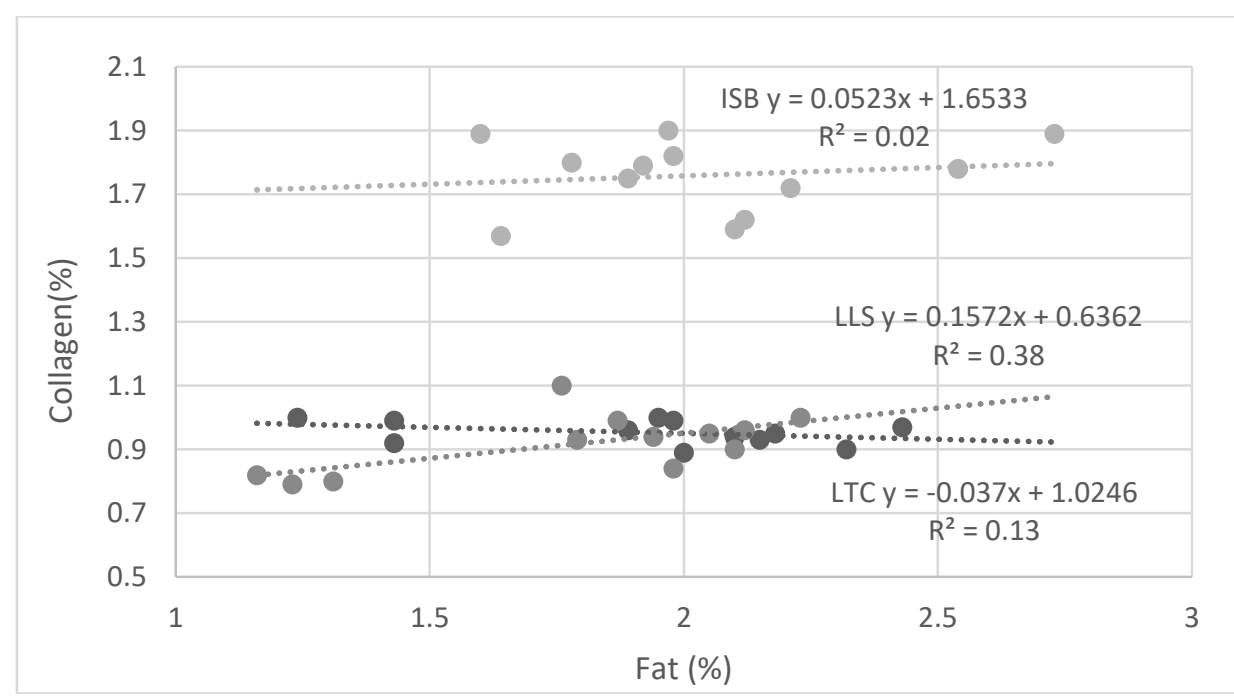

Figure 6. Relationship between fat (\%) and collagen content (\%) of various bovine muscles: ISB - Infraspinatus of a blade; LLS - Longissimus lumborum of striploin; LTC - Longissimus thoracis of a cube 


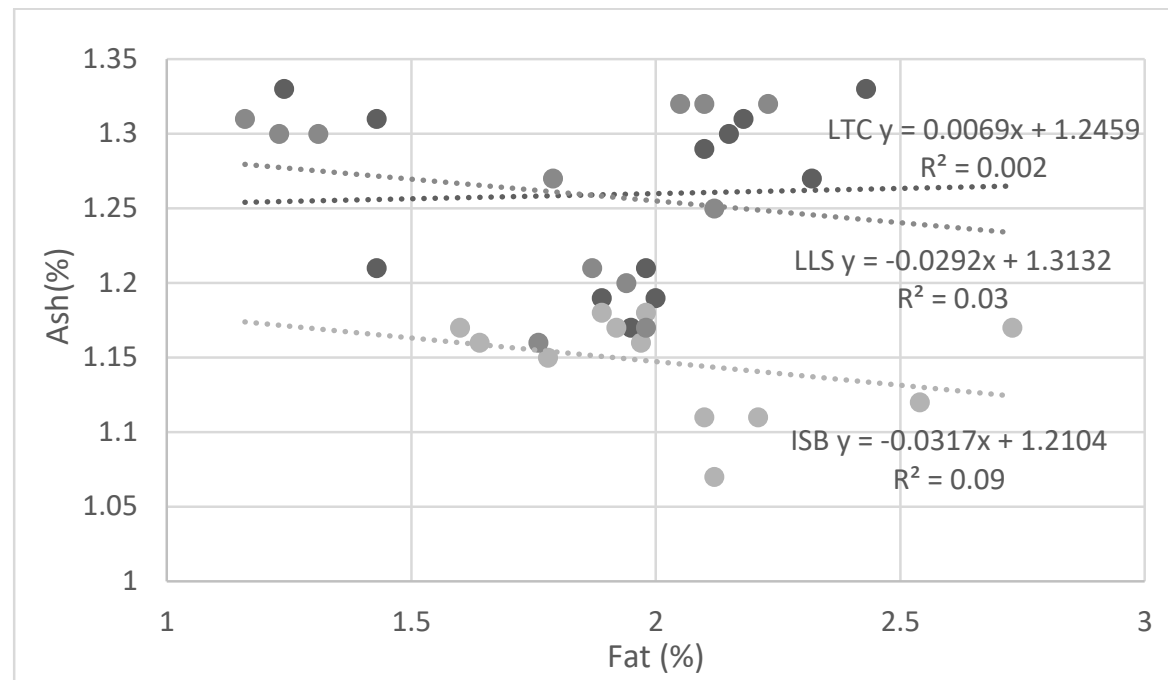

Figure 7. Relationship between fat $(\%)$ and ash content $(\%)$ of various bovine muscles: ISB - Infraspinatus of a blade; LLS - Longissimus lumborum of striploin; LTC - Longissimus thoracis of a cube

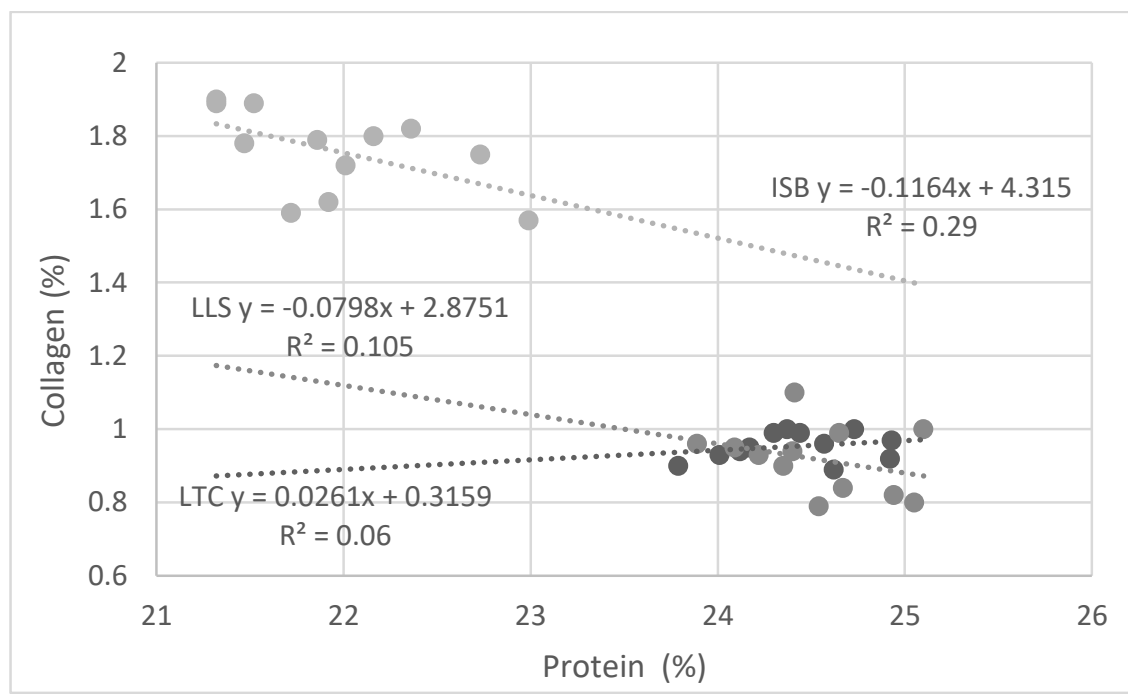

Figure 8. Relationship between protein (\%) and collagen content (\%) of various bovine muscles: ISB Infraspinatus of a blade; LLS - Longissimus lumborum of striploin; LTC - Longissimus thoracis of a cube

Table 5. Correlations between the share of feeds in the diet and selected meat parameters in different muscles

\begin{tabular}{|c|c|c|c|c|c|}
\hline & Meat parameter & \multicolumn{4}{|c|}{ Diet component } \\
\cline { 2 - 6 } & & grass silage & maise silage & meadow hay & concentrates \\
\hline \multirow{4}{*}{$\begin{array}{c}\text { Infraspinatus of blade } \\
\text { (ISB) }\end{array}$} & Moisture & 0.32 & $-0.73^{*}$ & -0.25 & 0.22 \\
\cline { 2 - 6 } & Fat & 0.00 & 0.28 & $-0.67^{*}$ & $-0.86^{*}$ \\
\cline { 2 - 6 } & Protein & 0.32 & $-0.62^{*}$ & 0.17 & $0.59^{*}$ \\
\cline { 2 - 6 } & Ash & 0.03 & -0.12 & 0.18 & 0.26 \\
\cline { 2 - 6 } & Collagen & 0.08 & 0.14 & -0.19 & -0.26 \\
\hline \multirow{4}{*}{$\begin{array}{c}\text { Longissimus lumborum of } \\
\text { striploin (LLS) }\end{array}$} & Moisture & -0.29 & -0.27 & 0.58 & $0.69^{*}$ \\
\cline { 2 - 6 } & Fat & -0.43 & $0.71^{*}$ & -0.15 & $-0.65^{*}$ \\
\cline { 2 - 6 } & Protein & 0.06 & -0.32 & 0.20 & 0.41 \\
\cline { 2 - 6 } & Ash & 0.02 & -0.20 & -0.05 & 0.07 \\
\cline { 2 - 6 } & Collagen & 0.24 & 0.28 & $-0.66^{*}$ & $-0.80^{*}$ \\
\cline { 2 - 6 } $\begin{array}{c}\text { Longissimus thoracis of } \\
\text { cube (LTC) }\end{array}$ & Moisture & -0.24 & -0.32 & 0.43 & $0.58^{*}$ \\
\cline { 2 - 6 } & Fat & -0.43 & $0.69 *$ & -0.26 & $-0.76^{*}$ \\
\cline { 2 - 6 } & Protein & 0.06 & -0.32 & 0.20 & 0.41 \\
\cline { 2 - 6 } & Ash & -0.15 & -0.15 & 0.03 & 0.09 \\
\hline
\end{tabular}


It is imperative to assess the chemical composition of meat because it determines its nutritional value and suitability for processing. The values for assessed meat parameters are consistent with results reported by Prevolnik et al., (2004), Guzek et al., (2013) and Wyrwisz et al. (2012). According to Litwińczuk et al., (2006), the average water content in the muscle of the longissimmus lumborum from young slaughter cattle of the Polish HolsteinFriesian Black-and-White cattle was $75.9 \%$ with $21.3 \%$ of protein and $1.3 \%$ of fat. Florek et al., (2007) reported the content of basic chemical components at a similar level while emphasising that the variability in chemical composition for beef depends on age, breed, muscle type, gender, the degree of muscle mass, carcass fatness, category of cattle acc. to EUROP-classification system.

The beef protein content and amino acid profile are not influenced by nutrition and genetics (Van Elswyk et al., 2014). None of the studies compared protein content of grass/forage-fed to grain-finished

\section{CONCLUSIONS}

The obtained results of assessing the chemical composition of three different muscles showed that the finishing diet composition might shape some meat parameters. The response to the diet composition depends on the muscle. Among the assessed meat components, only the moisture and fat content depended on the diet composition in all cattle reported statistical or practical differences in response to feeding regime (Duckett et al., 2009; Duckett et al., 2013; Leheska et al., 2008)

Currently, consumers expect products with the lowest possible fat content and easily digestible protein. In this respect, the culinary beef cuts from animals fed with a diet composed of grass silage, hay, and concentrates (diet D1) had the lowest fat content and relatively high protein content. In terms of the raw product's technological suitability (based on collagen content and its proportion in total protein), the ISB was the most suitable.

Already earlier, the variability of the elemental meat composition of different types of beef muscles was indicated by Jeremiah et al. (2003), Prieto et al. (2009) and Chang et al. (2010), Wyrwisz et al. (2012). Additionally, these researchers identified many factors that could influence the results, such as muscle work intensity, the caloric content of the animal feed, methods and ageing, etc.

three muscles. A difference in the collagen content in the longissimus lumborum of striploin (LLS) and protein content in the infraspinatus muscle (ISB) was noted. No differences were stated in ash content. The D1 diet turned out to be the most beneficial due to the fastest gains and beneficial chemical composition of meat, the highest level of protein and the lowest fat content - the dietary features of meat most appreciated by consumers.

\section{REFERENCES}

1 .

2. Aldai, N., Lavín, P., Kramer, J.K.G., Jaroso, R., \& Mantecón, A.R. (2012). Breed effect on quality veal production in mountain areas: emphasis on meat fatty acid composition. Meat Science, 92, 687-696. DOI:10.1016/j.meatsci.2012.06.024

3. Biel, W., Czerniawska-Piątkowska, E., \& Kowalczyk, A. (2019). Offal chemical composition from veal, beef, and lamb maintained in organic production systems. Animals, 9, 489-499. DOI:10,33901ani9080489.

4. Blancoa, M., Jurie, C., Micol, D., Agabriel, J., Picard, B., \& Garcia-Launay, F. (2013). Impact of animal and management factors on collagen characteristics in beef: a meta-analysis approach. Animals, 7:7, 12081218. DOI: $10.1017 / \mathrm{S} 1751731113000177$

5. Chang, H.J., Xu, X.L., Li, C.B., Huang, M., Liu, D.Y., \& Zhou, G.H. (2010). A comparison of heatinduced changes of intramuscular connective tissue and collagen of beef semitendinosus muscle during water bath and microwave heating. Journal of Food Process Engineering, 34, 1-18. DOI: 10.1111/j.17454530.2009.00568.x

6. Christensen, M., Ertbjerg, P., Failla, S.,Sañudo, C., Richardson, R.I., Nute, G.R., Olleta, J.L., Panea, B., Albertí, P., Juárez, M., Hocquette, J.F., Williams, J.L. (2011). Relationship between collagen characteristics, lipid content and raw and cooked texture of meat from young bulls of fifteen European breeds. Meat Science, 87, 61-65. DOI: 10.1016/j.meatsci.2010.09.003

7. Choi, N.J., Enser, M., Wood, J.D., \& Scollan, N.D. (2000). Effect of breed on the deposition in beef muscle and adipose tissue of dietary n-3 polyunsaturated fatty acids. Animal Science, 71, 509-519. DOI: $10.1017 / \mathrm{S} 1357729800055417$ 
8. Duckett, S.K., Neel, J.P.S., Fontenot, J.P., \& Clapham, W.M. (2009). Effects of winter stocker growth rate and finishing system on: III. Tissue proximate, fatty acid, vitamin and cholesterol content. Journal of Animal Science, 87, 2961-2970. DOI: 10.2527 / jas.2009-1850

9. Duckett, S.K., Neel, J.P.S., Lewis, R.M., Fontenot, J.P., \& Clapham, W.M. (2013). Effects of forage species or concentrate finishing on animal performance, carcass and meat quality. Journal of Animal Science, 91, 1454-1467.

10. Florek, M., Litwińczuk, Z., Kędzierska-Matysek, M., Grodzki, T., \& Skałecki, P. (2007). Nutritional value of meat from musculus longissimus lumborum and musculus semitendinosus of young slaughter cattle. Medycyna Weterynaryjna, 63, 242-247.

11. Fraser, M.D., Davies, D.A., Vale, J.E., Nute, G.R., Hallett, K.G., Richardson, R.I., \& Wright, I.A. (2009). Performance and meat quality of native and continental cross steers grazing improved upland pasture or semi-natural rough grazing. Livestock Science, 123, 70-82. DOI: 10.1016/j.livsci.2008.10.008

12. French, P., O'Riordan, E.G., Monahan, F.J., Caffrey, P.J., Mooney, M.T., Troy, D.J., \& Moloney, A.P. (2001). The eating quality of meat of steers fed grass and/or concentrates. Meat Science, 57(4), 379-386. DOI:10.1016/S0309-1740(00)00115-7.

13. Guzek, D., Głąbska, D., Pogorzelski, G., Kozań, K., Pietras, J., Konarska, M., Sakowska, A., Głąbski, K., Pogorzelska, E., Barszczewski, J., \& Wierzbicka, A. (2013). Variation of meat quality parameters due to conformation and fat class in Limousin bulls slaughtered at 25 to 27 months of age. Asian Australasian Journal of Animal Sciences, 26(5), 716-722. DOI:10.5713/ajas.2012.12525.

14. ICAR (2018). Guidelines for Beef Cattle Production Recording - Section 3. The Global Standard for livestock data, 1-88.

15. Instytut Zootechniki. (2001).Normy żywienia bydła, owiec i kóz. Wartość pokarmowa pasz dla przeżuwaczy. Opracowanie według INRA (1988), Praca zbiorowa. Kraków, 218.

16. Jeremiah, L.E., Dugan, M.E.R., Aalhus, J.L., \& Gibson, L.L. (2003). Assessment of palatability attributes of the major beef muscles. Meat Science, 65, 985-992. DOI: 10.1016 / S0309-1740 (02) 00307-8

17. Keady, T.W.J., Gordon, A.W., \& Moss, B.W. (2013). Effects of replacing grass silage with maise silages differing in inclusion level and maturity on the performance, meat quality and concentrate-sparing effect of beef cattle. Animals, 7(5), 768-777. DOI:10.1017/S1751731112002364.

18. Keane, M.G., Drennan, M.J., \& Moloney, A.P. (2006). Comparison of supplementary concentrate levels with grass silage, separate or total mixed ration feeding, and duration of finishing in beef steers. Livestock Science, 103(1), 169-180. DOI:10.1016/j.livsci.2006.02.008.

19. Kenneth, J.M., Lenssen, A.W., Steven, L., \& Fales, S.L. (2020). Factors affecting forage quality. In: Forages: The science of grassland agriculture, II, $7^{\mathrm{TH}}$ Edition. Editor(s): Kenneth, J. M, Collins, M., Nelson, J., Redfearn, D.D., Wiley J., \& Sons. DOI: 10.1002/9781119436669.ch39

20. Kowalski, M.Z., \& Kański, J. (1993). WINWAR ver 1.30. [computer software] Komputerowy program wspomagający wyliczenie wartości pokarmowej pasz według systemu INRA 1988, AR Kraków.

21. Leheska, J.M., Thompson, L.D., Howe, J.C., Hentges, E., Boyce, J., Brooks, J.C., Shriver, B., Hoover, L., \& Miller, M.F. (2008). Effects of conventional and grass-feeding systems on the nutrient composition of beef. Journal of Animal Science, 8, 3575-3685. DOI: 10.2527 / jas.2007-0565

22. Litwińczuk, Z., Domardzki, P., Florek, M., \& Żółkiewski, P. (2016). Chemical composition, fatty acid profile, including health indices of intramuscular fat, and technological suitability of the meat of young bulls of three breeds included in a genetic resources conservation programme fattened within a low-input system. Animal Science Papers and Reports vol. 34 no. 4, 387-397.

23. Litwińczuk, Z., Florek, M., \& Pietraszek, K. (2006). Physico-chemical quality of meat from heifers and young bulls of the Black-and-White (B.W.) variety of Polish Holstein-Fresian breed, and commercial B.W. crossbreds sired by Limousine and Charolaise bulls. Animal Science Papers and Reports, 24, 179186.

24. Nogalski, Z., Wielgosz-Groth, Z., Purwin, C., Sobczuk-Szul, M., Mochol, M., Pogorzelska-Przybyłek, P., \& Winarski, R. (2014). Effect of slaughter weight on the carcass value of young crossbred ('Polish Holstein Friesian' $\times$ 'Limousin') steers and bulls. Chilean Journal of Agricultural Research, 74(1), 5966. DOI:10.4067/S0718-58392014000100010.

25. Pena-Torres E.F., Gonzales-Rios H., Avendano-Reyes L., Valenzuela-Grijalva N.V., Pinelli-Saavedra A. (2019). Hydroxycinnamic acids in animal production: pharmacokinetics, pharmacodynamics and grown 
productivity effects, Review. Revista Mexicana de Ciencias Pecuarias, 10, 2, 391-415. DOI.org/10.22319/rmcp.v10i2.4526

26. Pesonen, M., Joki-Tokola, E., \& Huuskonen, A. (2014). Effect of silage plant species concentrate proportion and sugar beet pulp supplementation on the performance of growing and finishing crossbred bulls. Animal Production Science, 54, 1703-1708.

27. Prevolnik, M., Čandek-Potokar, M., \& Škorjanc, D. (2004). Ability of NIR spectroscopy to predict meat chemical composition and quality - A review. Czech Journal of Animal Science, 49, 500-515. DOI:10.17221/4337-CJAS.

28. Prieto, N., Ross, D.W., Navajas, E.A., Nute, G.R., Richardson, R.I., Hyslop, J.J., Simm, G., \& Roehe, R. (2009). Online application of visible and near-infrared reflectance spectroscopy to predict chemicalphysical and sensory characteristics of beef quality. Meat Science, 83, 96-103. DOI: $10.1017 /$ S1751731110001618

29. Purwin, C., Wyżlic, I., Nogalski, Z., Sobczuk-Szul, M., Pogorzelska-Przybyłek, P., Lipiński, K., Wierzbowska, J., Starczewski, M., \& Michalski, J.P. (2016). The effect of grass silage quality and supplementary concentrate levels on feed intake and fattening performance of crossbred steers. Journal of Elementology, 21(4), 1103-1113. DOI:10.5601/jelem. 2015.20.4.1061.

30. Randby, A.T., Nørgaard, P., \& Weisbjerg, M.R. (2010). Effect of increasing plant maturity in timothydominated grass silage on the performance of growing/finishing Norwegian Red bulls. Grass and Forage Science, 65(3), 273-286. DOI:10.1111/j.1365-2494.2010.00745.x.

31. Seremak Bulge, J. (2014). Rynek rolny. 2013-2014, IERiGŻ - PIB Warszawa.

32. Standards of Poland. (2010). PN-A-82109:2010. Mięso i przetwory mięsne. Oznaczanie zawartości tluszczu, białka $i$ wody. Metoda spektrometrii transmisyjnej $w$ bliskiej podczerwieni (NIT) $z$ wykorzystaniem kalibracji na sztucznych sieciach neuronowych (ANN)

33. Standards of Poland. (2019). PN-EN ISO 12099:2017-10. Pasze, ziarno zbóż i produkty przemiału Wytyczne stosowania spektrometrii bliskiej podczerwieni. 36.

34. Steen, R.W.J., Kilpatrick, D.J., \& Porter, M.G. (2002). Effects of the proportions of high or medium digestibility grass silage and concentrates on beef cattle's diet on live weight gain, carcass composition, and fatty acid composition of muscle Grass and Forage Science, 57(3), 279-291. DOI:10.1046/j.13652494.2002.00326.x.

35. Van Elswyk, M.E., \& McNeill, S.H. (2014). Impact of grass/forage feeding versus grain finishing on beef nutrients and sensory quality: The U.S. experience, Meat Science, Vol. 96, 1, 535-540. DOI: 10.1016 / j.meatsci.2013.08.010

36. Webb, E. (2006). Manipulating beef quality through feeding. South African Journal of Animal Science, 7, 5-15. http://www.sasas.co.za/Popular/Popular.html.

37. Wyrwisz, J., Półtorak, A., Zalewska, M., Zaremba, R., \& Wierzbicka, A. (2012). Analysis of relationship between basic composition, $\mathrm{pH}$, and physical properties of selected bovine muscles. Bulletin of the Veterinary Institute in Puławy, 56, 403-409, DOI:10.2478/v10213-012-0071-8. 